\title{
Effect of phosphorus doses to obtain higher yields in the cultivation of garlic (Allium sativum L.), at the district of Barranca \\ [Efecto de las dosis de fósforo para obtener mayor rendimiento en el cultivo de ajo (Allium sativum L.), en el distrito de Barranca]
}

Lady Milagros Vergara Santillan, José Antonio Legua Cárdenas ${ }^{\text {(D) }}$, José Vicente Nunja García ${ }^{(D)}$, Marco Antonio Jamanca Ramirez ${ }^{b}$ (D), Miguel Angel Inga Sotelo ${ }^{c}(\mathbb{D})$, Javier Enrrique Sotelo Montes ${ }^{b}(\mathbb{D}$, Eugenio Javier Gómez Gamarrad(iD, Dante Daniel Cruz Nietoa, ${ }^{*}$ (iD

aUniversidad Nacional José Faustino Sánchez Carrión

bUniversidad Nacional Santiago Antúnez de Mayolo

cUniversidad Nacional de Barranca

dInstituto de Educación Superior Tecnológico Público "Eleazar Guzmán Barrón" - Huaraz

*daniel2262@hotmail.com

Received: 1 September 2021; Accepted: 14 September 2021; Published: 23 September 2021

\section{Resumen}

La investigación trata sobre la fertilización de fósforo para obtener mayor rendimiento en cultivo de ajo. El objetivo fue determinar la dosis adecuada de fertilización foliar fósforo, para obtener mayor rendimiento en cultivo de ajo. La metodología se basa en la investigación aplicada y experimental; por lo que se empleó el Diseño de Bloques Completamente al Azar compuesto por 4 bloques y 5 tratamientos los cuales fueron $T_{1}=00, T_{2}=250, T_{3}=500, T_{4}=750, T_{5}=1000 \mathrm{~mL}$ de fósforo (Wuxal fósforo) /200 L. agua y se aplicaron a los 15, 30 y 45 días después de la siembra. Se evaluaron desde la siembra hasta poscosecha y los datos se procesaron con análisis de varianza y Duncan. Asimismo, se analizaron concentraciones de fósforo en hojas. Los resultados determinaron que $T_{4}$ sobresalió en longitud de tallo con $35.28 \mathrm{~cm}$, rendimiento comercial con $11.208 \mathrm{tn} / \mathrm{ha}$, peso de bulbo con $34.28 \mathrm{~g}$, número de bulbillos con 13 y análisis foliar destacó $\mathrm{T}_{5}$ con $0.48 \mathrm{~g} / 100 \mathrm{~g}$ m.s. (materia seca). Se concluye que la dosis $\mathrm{T}_{4}$ con $750 \mathrm{~mL}$ de fósforo (Wuxal Fósforo)/200 L de agua incremento $13.01 \%$ en rendimiento con relación al $\mathrm{T}_{1}$; siendo significativo.

Palabras clave: Ajo, fósforo, dosis y rendimiento.

\begin{abstract}
The research deals with phosphorus fertilization to obtain higher yields in garlic cultivation. The objective was to determine the appropriate dose of foliar phosphorus fertilization, to obtain a higher yield in garlic cultivation. The methodology is based on applied and experimental research; Therefore, the Completely Random Block Design was used, composed of 4 blocks and 5 treatments which were $T_{1}=00, \mathrm{~T} 2=250, \mathrm{~T}_{3}=500, \mathrm{~T}_{4}=750, \mathrm{~T}_{5}=1000 \mathrm{~mL}$ of phosphorus (Wuxal phosphorus)/200 L. water and were applied 15, 30 and 45 days after sowing. They were evaluated from sowing to postharvest and the data were processed with analysis of variance and Duncan. Likewise, phosphorus concentrations in leaves were analyzed. The results determined that $T_{4}$ stood out in stem length with $35.28 \mathrm{~cm}$, commercial yield with $11.208 \mathrm{tn} / \mathrm{ha}$, bulb weight with 34.28 $\mathrm{g}$, number of bulblets with 13 and foliar analysis highlighted $T_{5}$ with $0.48 \mathrm{~g} / 100 \mathrm{~g}$ d.s. (dry material). It is concluded that the $\mathrm{T}_{4}$ dose with $750 \mathrm{~mL}$ of phosphorus (Wuxal Phosphorus)/200 L of water increased $13.01 \%$ in yield in relation to $T_{1}$; being significant.
\end{abstract}

Keywords: Garlic, phosphorus, dose and yield. 


\section{SE \\ Journal of Sciences and Engineering}

Vol. 5, $\mathrm{N}^{\circ} 2,2021$

Copyright @ 2021, CINCADER.

ISSN 2523-9503

DOI: https://doi.org/10.32829/sej.v5i2.138

\section{Introduction}

Fertilizers have not been properly applied for many years; since the variation in the use of chemical inputs has affected the crops in the area, causing problems such as stress in the plant due to accumulation or deficiency of nutrients, pollution to the environment and an increase in the cost of production. This is due to the fact that synthetic fertilizers are increasingly used in order to increase yield without taking into account soil analysis, according to Rodríguez et al. (2019) show that modern agricultural practices accelerate soil contamination by the intensive use of fertilizers and pesticides to increase productivity and reduce crop losses.

Due to this situation, it is important to do the soil analysis to determine the phosphorus concentration; because in soils of low concentration it makes its availability difficult for the absorption of the plant, for which the addition of this nutrient is required; since it intervenes in biochemical reactions such as energy transport and promotes optimal absorption of other nutrients Gueçaimburu, et al. (2019), argue that the level of phosphorus (P) available in the soil is a dynamic variable, influenced by the properties of the soil, the plant and environmental conditions. Physical degradation processes affect soil structure and nutrient availability. Likewise, FAO (2002) affirms that phosphorus supplies 0.1 to 0.4 percent of the dry extract of the plant, it is important in energy transfer. That is why it is essential for photosynthesis and in its physiology and essential for development.

Therefore, phosphorus-based fertilization influences resistance and protection against adverse factors such as pests, diseases, climate change and reduces the cost of production. Therefore, it favors in the architecture of the plant, good development of the garlic crop and therefore in the yield. This statement is supported by Becerra (2007), who exposes phosphorus is a macronutrient that is part of the nucleoproteins, lipoids and phospholipids; plays an important metabolic role in respiration and photosynthesis (phosphorylation), in energy storage and transfer (NAD, NADP, and ATP), and in cell division and growth.

However, it is necessary to highlight that due to the variation of nutrients in the soil, the use of pesticides and other factors that affect crops, foliar fertilization is a technique of supplying nutrients in a direct, effective, homogeneous way and facilitating the availability of nutrients in vegetable crops, which favors development and therefore yield. This analysis is supported by Molina (2002), who mention foliar fertilization is the principle of application of nutrients through the foliar tissue, mainly through the leaves, which are the organs where the greatest physiological activity of the plant is concentrated; however, it is not a substitute for soil fertilization, but it is a recommended practice to complement soil nutrition.

Therefore, the foliar application of phosphorus applied as a liquid compound in the vegetative stage of vegetable crops provides chemical ingredients of phosphorus compounds; that influence the biochemical reactions of energy formation and transport, promote the availability of other nutrients such as nitrogen and the formation of carbohydrates, which results in good development, greater resistance to adverse factors and performance. According to Gonzáles et al. (2020), conclude that after 13 weeks, the hardening period of Aextoxicon punctatum plants (tree called Olivillo), no significant differences were observed between the treatments for the morphological variables and root growth potential. However, treatments with applications of $300 \mathrm{mg} / \mathrm{L}$ of phosphorus generated the highest concentrations at the foliar level of nitrogen and the lowest of calcium. 


\section{SE \\ Vol. 5, $\mathbf{N}^{\circ}$ 2, 2021}

Copyright @ 2021, CINCADER.

ISSN 2523-9503

DOI: https://doi.org/10.32829/sej.v5i2.138

\section{Materials and Methods}

\section{Kind of investigation}

The experiment is based on type of applied and experimental research; since by means of evaluations and statistical analysis, the recommended dose of phosphorus application that obtained the highest yield in the garlic crop was determined.

\section{Location and weather conditions}

The experimental area is located in the district of Barranca located in the province of Barranca, Fundo Santa Margarita, which borders the Buena Vista Human Settlement to the north, to the South with the San Ildefonso de Barranca Cemetery, to the West with the Finca Santa Margarita and the East with Centro Poblado Pampa Velarde. It is also located the coordinates of south latitude $10^{\circ} 46^{\prime} 0.18$ "and west longitude $77^{\circ} 44^{\prime} 17.8^{\prime \prime}$ and altitude of 84 m.s.n.m (meters above sea level). Regarding the climate conditions, the temperature was $23^{\circ} \mathrm{C}$ and $25^{\circ} \mathrm{C}$ average, the relative humidity was $84 \%$ and the soil is of the sandy loam type (See figure 1 ).

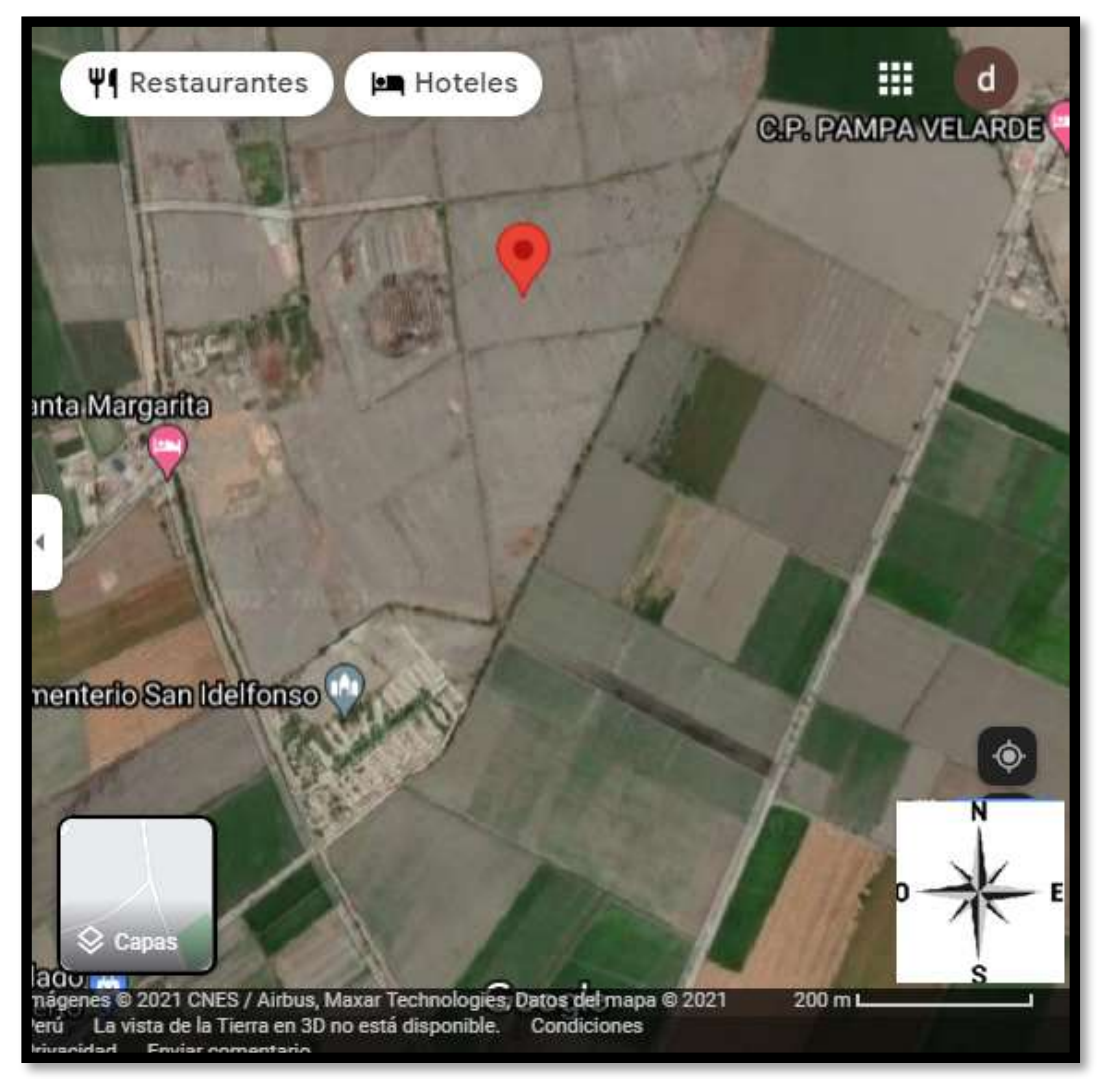

Figure 1: Location of the experimental area

Source: Google maps., 2021

\section{Soil analysis}

For the soil analysis the following procedures were carried out, soil samples were taken in a staggered manner and it was poured into a blanket then it was stirred and from there a representative sample of $1 \mathrm{Kg}$ of soil was taken, which was taken to the National Institute of Innovation Agrarian (INIA) - Huaral, which was determined that the soil does not present danger 
Vol. 5, $\mathrm{N}^{\circ} 2,2021$

Copyright @ 2021, CINCADER.

ISSN 2523-9503

DOI: https://doi.org/10.32829/sej.v5i2.138

\section{SE \\ Journal of Sciences and \\ Engineering}

of salts, $\mathrm{pH}$ is neutral, has a low concentration of potassium with $92 \mathrm{ppm}(12 \mathrm{ppm}-250 \mathrm{ppm}$ ) and available phosphorus with $8 \%(12 \mathrm{ppm}-36 \mathrm{ppm})$.), average concentration of organic matter with $2.62 \%(2 \%-4 \%)$, nitrogen with $0.13 \%(0.1 \%-0.2 \%)$ and normal concentration of calcium carbonate. Therefore, these results define that the soil is in sowing conditions for the garlic crop; however it is necessary to apply organic matter; since it favors the incorporation of nutrients.

Table 1. Basic soil fertility analysis for garlic cultivation

\begin{tabular}{|c|c|c|c|c|c|c|c|c|c|c|}
\hline E.C. & $\begin{array}{c}\mathrm{pH} \\
1: 2.5\end{array}$ & O.M. & $\mathrm{N}$ & $P$ & $K$ & $\begin{array}{c}\mathrm{CaCo}_{3} \\
\%\end{array}$ & & $\begin{array}{l}\text { Cation exchange } \\
\text { (mEq/100 g soil) }\end{array}$ & & CEC \\
\hline $\begin{array}{c}\mathrm{mS} / \mathrm{cm} \\
1.50\end{array}$ & 7.13 & $\begin{array}{c}\% \\
2.62\end{array}$ & $\begin{array}{c}\% \\
0.13\end{array}$ & $\begin{array}{c}\mathrm{ppm} \\
8\end{array}$ & $\begin{array}{c}\text { ppm } \\
92\end{array}$ & 0.88 & $\begin{array}{c}\mathrm{Ca} \\
15.06\end{array}$ & $\begin{array}{cc}\mathrm{Mg} & \mathrm{Na} \\
0.87 & 0.19\end{array}$ & $\begin{array}{c}\mathrm{K} \\
0.24\end{array}$ & 16.36 \\
\hline
\end{tabular}

Source: INIA (2018), Basic soil fertility analysis.

Note: E.C: Electrical conductivity

O.M.: Organic matter

mEq.: Milli equivalent

CEC: Cation exchange capacity

ppm: Parts per million

\section{Phosphorus in the soil}

According to the results of the soil analysis carried out in INIA - Huaral, it was determined that the phosphorus concentration was $8 \mathrm{ppm}$ in the soil, so this concentration is low. Due to this value, it is analyzed that it lacks phosphorus availability for garlic cultivation. Therefore, phosphorus-based fertilization is required; since according to the values according to Agrolab (2005), it mentions that the average values of phosphorus in the soil according to the Olsen method is $10-20 \mathrm{ppm}$, for plant availability (See table 2).

Table 2. Determination of phosphorus in the soil

\begin{tabular}{lccc}
\hline Element & $\begin{array}{c}\text { Total concentration of } \\
\text { phosphorus compounds } \\
\text { (mg/L solution) }\end{array}$ & $\begin{array}{c}\text { Normal } \\
\text { values } \\
\text { mg/L solution }\end{array}$ & Calification \\
\hline phosphorus & 8 & $12-36$ & Low \\
\hline
\end{tabular}

Source: INIA (2018), Basic soil fertility analysis

\section{Macronutrient fertilization recommendation}

Regarding the fertilization analysis carried out in INIA - Huaral, he recommended the following amounts of macronutrients, which were applied 25 days after sowing (dds) $1 / 3$ of $\mathrm{N}, 100 \% \mathrm{P}_{2} \mathrm{O}_{5}$ and $100 \% \mathrm{~K}_{2} \mathrm{O}$ and at 40 dds with $1 / 3$ of $\mathrm{N}$ and 65 dds with $1 / 3 \mathrm{~N}$, in the sources and total amounts of Urea with $279,773 \mathrm{~kg} / \mathrm{ha}$, Diammonium Phosphate with $173,913 \mathrm{~kg} / \mathrm{ha}$ and Potassium Sulfate with $240 \mathrm{~kg} / \mathrm{ha}$. It is also worth mentioning that Urea has $46 \% \mathrm{~N}$, Diammonium Phosphate $18 \%$ $\mathrm{N}$ and $46 \% \mathrm{P}_{2} \mathrm{O}_{5}$ and Potassium Sulfate with $50 \% \mathrm{~K}_{2} \mathrm{O}$ (see table 3).

Table 3. Recommended fertilization dose for garlic cultivation

\begin{tabular}{lrrr}
\hline Culture & \multicolumn{3}{c}{ Dose $(\mathrm{kg} / \mathrm{ha})$} \\
\hline \multirow{2}{*}{ Garlic } & $\mathrm{N}$ & $\mathrm{P}_{2} \mathrm{O}_{5}$ & $\mathrm{~K}_{2} \mathrm{O}$ \\
& 160 & 80 & 120
\end{tabular}

Source: INIA (2018), Basic soil fertility analysis 


\section{Journal of Sciences and Engineering}

Vol. 5, $\mathrm{N}^{\circ} 2,2021$

Copyright (C) 2021, CINCADER.

ISSN 2523-9503

DOI: https://doi.org/10.32829/sej.v5i2.138

\section{Treatments}

To obtain the foliar application doses of phosphorus (Wuxal Phosphorus), the results of the soil analysis indicating phosphorus deficiency and the doses used by farmers in the Barranca district were taken into account; therefore, the doses and the control were established (see table 4). It is necessary to mention that the application was made 15, 30 and 45 days after sowing. Therefore, it is important to determine the appropriate dose of phosphorus in order to obtain a higher yield in garlic cultivation, according to Egoávil (2014), he states that nitrogen together with phosphorus are the macronutrients that most frequently limit the growth of the plants. Nitrogen is very versatile, it exists in different forms (inorganic and organic) and with different oxidation states.

Table 4: Dose of foliar phosphorus fertilization for garlic cultivation

\begin{tabular}{cc}
\hline Treatments & $\begin{array}{c}\text { Relation between volume of } \\
\text { phosphorus /volume water }\end{array}$ \\
\hline$T_{1}$ & 0.00 \\
$T_{2}$ & 0.25 \\
$T_{3}$ & 0.50 \\
$T_{4}$ & 0.75 \\
$T_{5}$ & 1.00 \\
\hline
\end{tabular}

\section{Experiment procedures}

The procedures were carried out as follows:

The representative experimental area was established in the district of Barranca and the preparation was carried out in a conventional manner; that is to say, as the farmers of the area do it.

Next, an experiment was installed using the Completely Random Block Design, which consisted of 4 blocks and 5 treatments. These doses are detailed in Table 4.

Then they were sown in $0.10 \mathrm{~m}$ distance between plants, between a twin row of $0.55 \mathrm{~m}$ and one garlic was placed per hit.

Afterwards, the phosphorus doses were applied at 15, 30 and 45 days after sowing and the physical characteristics were evaluated from sowing to postharvest.

Obtained the data of the physical characteristics were processed with the analysis of variance and Duncan's test at 5\% error, which determined if there was homogeneity or variation of treatments and which one stood out.

Finally, representative leaves of each treatment were collected and taken to the INIA - Huaral, which determined that the phosphorus concentration influenced the yield of the garlic crop 


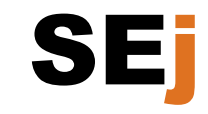

Vol. 5, $\mathrm{N}^{\circ} 2,2021$
Journal of Sciences and

Engineering

Copyright (C) 2021, CINCADER.

ISSN 2523-9503

DOI: https://doi.org/10.32829/sej.v5i2.138

\section{CINCADER}

Centre of Research and Training for

Regional Development

Online at www.journals.cincader.org

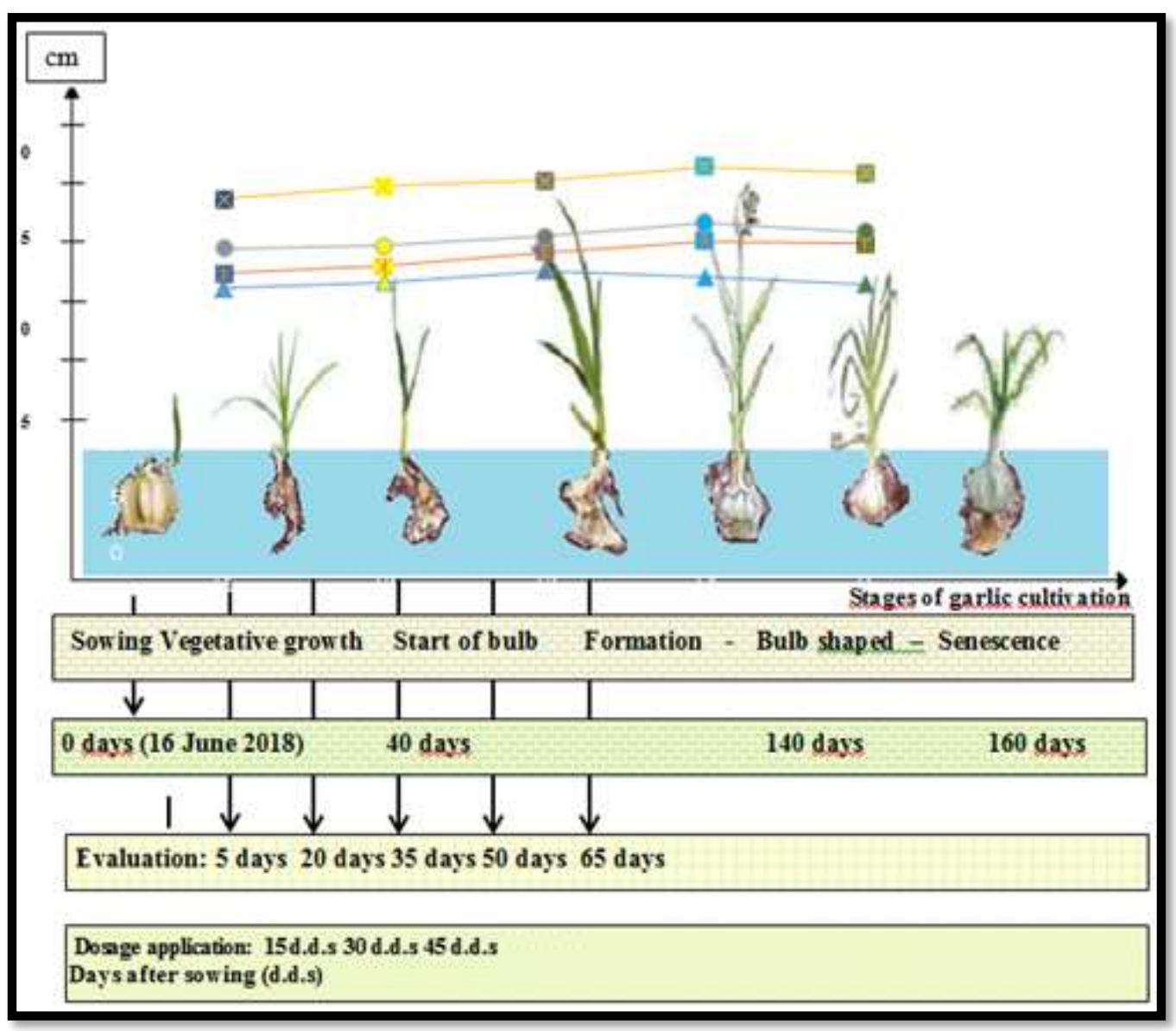

Figure 2: Phosphorus application date and evaluation

\section{Results}

According to the results of the application of the foliar phosphorus in the garlic crop that are detailed in table 5, it was determined that there was only dose effect on commercial yield and number of bulblets; however, in the other evaluations there were no significance. This result is analyzed to be favorable because they excelled in yield, which is recommended for farmers in the area. This is due to the fact that phosphorus influences the biochemical development of energy transport, obtaining greater resistance to adverse factors of nutrition, climate, pests and diseases; according to Díaz, et al. (2013) mention that phosphorus is an essential macroelement for plants and together with environmental factors, such as radiation and temperature, influences the growth and yield of crops such as corn. 


\section{Journal of Sciences and Engineering}

Vol. 5, $\mathrm{N}^{\circ} 2,2021$

Copyright @ 2021, CINCADER.

ISSN 2523-9503

DOI: https://doi.org/10.32829/sej.v5i2.138

Table 5. Results of the physical characteristics of the garlic crop

\begin{tabular}{|c|c|c|c|c|c|}
\hline \multirow[b]{2}{*}{ Treatment } & \multicolumn{2}{|c|}{ Field evaluation } & \multicolumn{3}{|c|}{ Postharvest evaluation } \\
\hline & Stem length $(\mathrm{cm})$ & $\begin{array}{l}\text { Commercia } \\
\text { yield }(t n)\end{array}$ & $\begin{array}{l}\text { Bulb weight } \\
\text { (g) }\end{array}$ & $\begin{array}{l}\text { Equatorial } \\
\text { diameter }(\mathrm{cm})\end{array}$ & $\begin{array}{l}\text { Number of } \\
\text { bulbils }\left(\mathrm{N}^{\circ}\right)\end{array}$ \\
\hline$\overline{T_{4}}$ & $35.288 \mathrm{a}$ & $11.2080 \mathrm{a}$ & $34.285 \mathrm{a}$ & $6.178 \mathrm{a}$ & $12.875 \mathrm{a}$ \\
\hline $\mathrm{T}_{5}$ & $34.688 a b$ & $10.8810 \mathrm{a}$ & $33.152 \mathrm{a}$ & $5.426 \mathrm{ab}$ & $12.450 \mathrm{~b}$ \\
\hline $\mathrm{T}_{3}$ & $34.000 a b$ & $10.2210 \mathrm{ab}$ & $32.668 \mathrm{a}$ & $4.943 a b$ & $12.275 \mathrm{bc}$ \\
\hline $\mathrm{T}_{2}$ & $33.525 \mathrm{ab}$ & $9.3523 \mathrm{cb}$ & $31.281 \mathrm{a}$ & $4.786 a b$ & $11.950 \mathrm{c}$ \\
\hline $\mathrm{T}_{1}$ & $32.300 \mathrm{~b}$ & $8.6705 \mathrm{c}$ & $29.511 \mathrm{a}$ & $4.684 \mathrm{~b}$ & $11.200 \mathrm{~d}$ \\
\hline Significance & ** & * & ** & ** & * \\
\hline VC \% & 4.97 & 8.74 & 16.19 & 14.09 & $2.21 \%$ \\
\hline
\end{tabular}

Note: VC \% (Percentage of coefficient of variation)

\section{Stem length}

Process the stem length data through analysis of variance that is indicated in table 5, it was determined that there was no significance and the coefficient of variation was $4.97 \%$, which indicates a slight variation of plot averages. Therefore, it is analyzed that the foliar application of phosphorus did not influence the size of the plant; but it stood out in the $T_{4}$ with $35.28 \mathrm{~cm}$ in relation to the others. This is due to the fact that phosphorus influences the biochemical reactions of energy formation and transport and promotes the absorption of other nutrients favoring the development of the crop. Mentioned this analysis is supported by Fernández (2007), who affirms that phosphorus is an essential element for the growth and development of plants. Most soils are deficient in assimilable forms of phosphorus, so the application of phosphorous fertilizers is required to achieve high levels of productivity.

\section{Business performance}

Regarding the statistical analysis of the commercial yield that is detailed in table 5, it was determined that there was an effect of phosphorus dose and the coefficient of variation was $8.74 \%$, which means there is a slight variation of plot averages. Therefore, it is analyzed that phosphorus influenced the yield of the garlic crop that stood out in $\mathrm{T}_{4}$ with $11,2080 \mathrm{tn} / \mathrm{ha}$; which is equivalent to an increase of $13.01 \%$ in relation to $T_{1}$ with $11,200 \mathrm{tn} / \mathrm{ha}$. This is due to the fact that an adequate dose of foliar phosphorus favored the biochemical reactions of formation, energy transport, promoted the absorption of other nutrients, which influenced the optimal formation of carbohydrates and therefore in the yield. The above is supported by Contreras, (2016) who concludes the interactions of copper and phosphorus had a positive effect on the percentage of milling yield (rice), being significant with the control and with the treatment that have $\mathrm{Cu}, \mathrm{Zn}$ and B more match.

\section{Bulb weight}

Regarding the postharvest statistical analysis, in this case the bulb weight that is detailed in table 5 , it was determined that there was no significance and the coefficient of variation was $16.19 \%$. These results are due to the fact that the application of phosphorus did not influence performance; however, it stood out in $T_{4}$ with $34.28 \mathrm{~g}$, in relation to the other treatments. Therefore, at an adequate dose of phosphorus, it promoted the absorption of other nutrients, which strengthened the architecture of the plant against factors of damage from pests, diseases and reduced pollution to the environment. This analysis is supported by Eugenio J. (2016) with the application of potassium phosphate, the best results were obtained, reporting a lower percentage of incidence $(12.73 \%)$ and severity at 90 days $(20.21 \%)$, a consequence of this, the plants experienced greater 


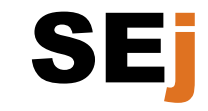

Vol. 5, $\mathrm{N}^{\circ} 2,2021$

\section{Journal of Sciences and Engineering}

Copyright (C 2021, CINCADER.

ISSN 2523-9503

DOI: https://doi.org/10.32829/sej.v5i2.138
Centre of Research and Training for

Regional Development

Online at www.journals.cincader.org

growth in leaf length at 90 days $(87.37 \mathrm{~cm})$, as well as equatorial diameter $(6.72 \mathrm{~cm})$ and bulb weight $(154.60 \mathrm{~g})$,

\section{Equatorial diameter}

Following with the postharvest evaluation, the statistical analysis of equatorial diameter indicated in table 5 was carried out, which was determined by means of the analysis of variance, there was no effect of phosphorus dose and the coefficient of variation of $14.09 \%$ was obtained. These results are analyzed that the application of phosphorus did not influence the thickness of the bulb; however, the $T_{4}$ with $6.17 \mathrm{~cm}$ stood out compared to the others. Therefore, it is worth mentioning that an adequate dose of phosphorus favored the development of the plant and roots; which influenced the greater absorption of nutrients. Exposed, this analysis is based on Compo Expert (2021), who states that in the case of onion, it has relatively high phosphorus needs. This element is directly related to the development of the roots and, therefore, it is necessary to ensure an efficient absorption of the remaining nutrients, so its contribution is mainly essential at the beginning of the crop.

\section{Number of bulbils}

Concerning the statistical analysis of bulbillo that is detailed in table 5 , it can be seen that there was an effect of phosphorus dose and the coefficient of variation was $2.21 \%$. These results are interpreted that the application of phosphorus influenced the amount of bulblets per treatment. Likewise, it can be seen that $T_{4}$ with 13 bulbils stood out compared to the other treatments. This is because phosphorus influenced the development of the bulb, which strengthened against stress factors such as damage from pests and diseases and therefore improved the amount of bulb. The analysis is supported by Saavedra (2003), who investigated the effect on the yield of shallot (onion), when using different sizes of bulb and different levels of phosphorus and amendment with lime. It determined that the best yields of shallot bulbs were obtained with the highest doses of phosphorus and the highest doses of lime.

\section{Foliar analysis}

In the chemical analysis of phosphorous concentration, the representative samples of leaves were analyzed by treatments in INIA-Huaral, which determined that the $T_{5}$ with $0.48 \mathrm{~g} / 100 \mathrm{~g} \mathrm{~d}$.m. (dry matter) obtained higher concentration; however, the $T_{4}$ with $0.34 \mathrm{~g} / 100 \mathrm{~g} \mathrm{~d} . \mathrm{m}$. stood out in higher commercial yield with 11,208 tn/ha. Therefore, it is analyzed that at this concentration of phosphorus it promoted the optimal use of nutrients such as nitrogen for the development of the plant, which increased yield. According to Singh et al. (2015) who affirm that the photosynthetic capacity and, therefore, chlorophyll, are directly related to the phosphorus and nitrogen content in the plant.

Table 6. Results of phosphorus concentration in leaf foliar area (g/100 g d.m.)

\begin{tabular}{lccccc}
\hline Treatment & $\begin{array}{c}\text { Dose } \mathrm{mL} / 200 \\
\text { L of water }\end{array}$ & $\begin{array}{c}\text { Results } \\
\text { g/100 } \\
\text { g.d.m. }\end{array}$ & Qualification & $\begin{array}{r}\text { Normal values } \\
\text { g/100 g.d.m. }\end{array}$ & $\begin{array}{c}\text { Performance } \\
\text { tn/ha }\end{array}$ \\
\hline $\mathrm{T}_{1}$ & 0 & 0.10 & Low & $0.20-0.50$ & 8.6705 \\
$\mathrm{~T}_{2}$ & 250 & 0.19 & Low & $0.20-0.50$ & 9.3523 \\
$\mathrm{~T}_{3}$ & 500 & 0.21 & Normal & $0.20-0.50$ & 10.2210 \\
$\mathrm{~T}_{4}$ & 750 & 0.34 & Normal & $0.20-0.50$ & 11.2080 \\
$\mathrm{~T}_{5}$ & 1000 & 0.48 & Normal & $0.20-0.50$ & 10.8810 \\
\hline
\end{tabular}

Source: INIA (2018). Phosphorus analysis in leaves 


\section{Journal of Sciences and Engineering}

Vol. 5, $\mathrm{N}^{\circ}$ 2, 2021

Copyright @ 2021, CINCADER.

ISSN 2523-9503

DOI: https://doi.org/10.32829/sej.v5i2.138

\section{Conclusions}

It was determined that at an adequate dose of foliar phosphorus fertilization, which is $T_{4}$ with 750 $\mathrm{mL}$ of phosphorus (Wuxal Phosphorus)/200 L of water applied at 4 times to the garlic crop, it stood out with a yield of $11,208 \mathrm{tn} / \mathrm{ha}$; that is, there was an increase of $13.01 \%$ in relation to the control. Therefore, there was significance in performance with the application of this dose.

Regarding the foliar analysis, it was determined that $T_{5}$ with $0.48 \mathrm{~g}$ of phosphorus $/ 100 \mathrm{~g} \mathrm{d.m}$. it stood out in relation to the other treatments; however, the $T_{4}$ with $0.34 \mathrm{~g}$ of phosphorus $/ 100 \mathrm{~g}$ d.m. stood out in higher commercial performance; therefore, this concentration influenced the development, protection against stress factors and increased garlic yield.

Finally, it is concluded that foliar phosphorus fertilization influenced the development and protection of the garlic crop against adverse factors such as pests, diseases and the environment, which significantly increased the yield, bulb quality and therefore greater economic gain.

\section{References}

Agrolab, 2005, Guía de referencia para la interpretación análisis de suelos Agrolab, Análisis $\begin{array}{lllll}\text { Técnicos, S.A. } & \text { de } & \text { C.V. } & \text { 1-15. }\end{array}$ http://www.agrolab.com.mx/sitev002/sitev001/assets/interpretacion_fertsuel.pdf

Becerra L., Navia S., Ñústez C., 2007, Efecto de niveles de fósforo y potasio sobre el rendimiento del cultivar 'Criolla Guaneña' en el departamento de Nariño". Revista Latinoamericana de la papa, Vol. 14, № 1, pp. 51-60.

Compo Expert, 2021, Cebolla y ajo- Nutrición completa, eficiente e inmediata para obtener mayores rendimientos", información básica. https://www.compo-expert.com/esES/cultivos/verduras/cebolla-y-ajo

Contreras, L. 2016, Aplicación de fósforo y micronutrientes en un sistema intensivo del cultivo de arroz (Oryza sativa L.) CV. Tinajones en Jequetepeque" Tesis para Optar el Título de Ingeniero Agrónomo. Universidad Nacional Agraria La Molina, Perú.

Díaz E., Loeza J., Campos J., Morales E., Domínguez A., Franco O., 2013, Eficiencia en el uso de la radiación, tasa de asimilación neta e integral térmica en función del fósforo en maíz (Zea

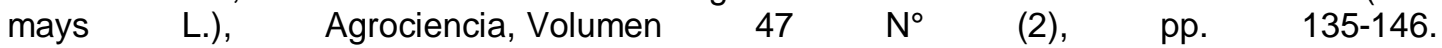
http://www.scielo.org.mx/scielo.php?script=sci_arttext\&pid=S1405-31952013000200003

Egoávil, C., 2014, Caracterización de suelos con fines de fertilidad en la provincia de Satipo Junín, Berú, Book, https://www.devida.gob.pe/documents/20182/335287/4.+Caracterizaci\%c3\%b3n+de+Suelos AVSI.pdf/411a6ca2-4d1a-4497-9012-2e1d2d3b9a33

Eugenio J., 2016, Efecto de la aplicación de tres productos ecológicos para la prevención de mildiu velloso (Peronospora destructor) en cebolla de bulbo (Allium cepa var. Regal)", Trabajo de Investigación previo a la obtención del Grado Académico de Magíster en Producción Agrícola Sustentable, Universidad Técnica De Ambato - Ecuador.

FAO, 2002, Los fertilizantes y su uso, una Guía de Bolsillo para los Oficiales de Extension. Food \& Agriculture Org, Organización de las Naciones Unidas para la Alimentación, World Fertilizer use Manual, IFA, París", http://www.fertilizer.org.

Fernández, M., 2007, Fósforo: amigo o enemigo, Instituto Cubano de Investigaciones de los Derivados de la Caña de Azúcar (ICIDCA). Sobre los Derivados de la Caña de Azúcar, Vol. 41, № 2, pp. 51-57. Ciudad de La Habana, Cuba.

González M., Ríos D., Peña K., García E., Acevedo M., Cartes E., Sánchez M., 2020, Efecto de la concentración de fósforo y calcio sobre atributos morfo-fisiológicos y potencial de crecimiento radical en plantas de Aextoxicon punctatum producidas a raíz cubierta en la etapa 
Vol. 5, $\mathrm{N}^{\circ}$ 2, 2021

\section{SE \\ Journal of Sciences and Engineering}

Copyright @ 2021, CINCADER.

ISSN 2523-9503

DOI: https://doi.org/10.32829/sej.v5i2.138
A publication of

\section{CINCADER}

Centre of Research and Training for

Regional Development

Online at www.journals.cincader.org

de endurecimiento", Revista Bosque, Volumen 41, $\mathrm{N}^{\circ} 2, \quad$ pp 137 - 146. http://dx.doi.org/10.4067/S0717-92002020000200137

Google maps., 2021, Ubicación del experimento, Mapa google. https://www.google.es/maps/place/10\%C2\%B046'01.8\%22S+77\%C2\%B044'17.8\%22W/@$10.76976,-77.7424279,1209 \mathrm{~m} /$ data $=! 3 \mathrm{~m} 1$ ! $1 \mathrm{e} 3 ! 4 \mathrm{~m} 6 ! 3 \mathrm{~m} 5 ! 1 \mathrm{~s} 0 \times 0: 0 \times 0 ! 7 \mathrm{e} 2 ! 8 \mathrm{~m} 2 ! 3 \mathrm{~d}-$ $10.7671743 ! 4 d-77.7382866$

Gueçaimburu J., Vázquez J., Tancredi F., Reposo G., Rojo V., Martínez M., Introcaso R., 2019, Evolución del fósforo disponible a distintos niveles de compactación por tráfico agrícola en un argiudol típico, Chilean journal of agricultural \& animal sciences, volumen. $35, \mathrm{~N}^{\circ} 1$, pp. 81 89. http://dx.doi.org/10.4067/S0719-38902019005000203

Instituto Nacional de Innovación Agraria (INIA-Huaral), 2018, Análisis básico fertilidad de suelos, para el cultivo de ajo en el distrito de Barranca. Hoja de resultados de análisis, Perú.

Instituto Nacional de Innovación Agraria (INIA-Huaral), 2018, Análisis foliar de fósforo, para el cultivo de ajo en el distrito de Barranca. Hoja de resultados de análisis, Perú.

Molina, E., 2002, Fuentes de fertilizantes foliares, Fertilización Foliar: Principios y Aplicaciones. Libro de Memoria, Laboratorio de suelos y foliares, pp. 26. http://www.cia.ucr.ac.cr/pdf/Memorias/Memoria\%20Curso\%20Fertilizaci\%C3\%B3n\%20Foliar.pdf

Rodríguez N., McLaughlin M., Pennock D., 2019, La contaminación del suelo: una realidad oculta, Organización de las Naciones Unidas para la Alimentación y la Agricultura (FAO), Roma, http://www.fao.org/3/i9183es/i9183es.pdf

Saavedra J., 2003, Efectos del tamaño de bulbo, niveles de fósforo y de enmienda con cal en rendimiento de chalota (Allium cepa var. Aggregatum G. Don)". Tesis presentada como parte de los requisitos para optar el grado de Licenciado en Agronomía. Universidad Austral de Chile. http://cybertesis.uach.cl/tesis/uach/2003/fas112e/pdf/fas112e.pdf

Singh, S. y Reddy, V., 2015, Respuesta de la asimilación de carbono y la fluorescencia de la clorofila al fósforo de la hoja de soja a través del CO2: Sumidero de electrones alternativo, eficiencia de nutrientes y concentración crítica, Journal of Photochemistry and Photobiology B: Biology. Vol. 151, pp. 271 -284, https://doi.org/10.1016/j.jphotobiol.2015.08.021 